\title{
Epistasis and the sensitivity of phenotypic screens for beta thalassaemia
}

\author{
Bridget Penman ${ }^{1 *}$, Sunetra Gupta ${ }^{1}$, David Weatherall ${ }^{2}$ \\ From Challanges in malaria research: Core science and innovation \\ Oxford, UK. 22-24 September 2014
}

Severe forms of alpha and beta thalassaemia have been estimated to affect approximately 68000 births annually. Individuals who carry thalassaemic genes are protected against death from malaria infection; the global distribution of thalassaemic genes thus matches the historical distribution of malaria.

Screening programmes are a vital tool to counter the thalassaemias by:

(i) identifying individual carriers and allowing them to make informed reproductive choices, and (ii) generating population level gene-frequency estimates, to help ensure the optimal allocation of public health resources. For both of these functions it is vital that the screen performed is suitably sensitive.

One popular first-stage screening option for beta thalassaemia in low-income countries is the One Tube Osmotic Fragility Test (OTOFT). Here we introduce a population genetic framework within which to quantify the likely sensitivity and specificity of the OTOFT in different epidemiological contexts. We demonstrate that the co-occurrence of alpha thalassaemia, and other malaria related erythrocyte poly-morphisms such as Southeast Asian Ovalocytosis and glucose-6-phosphate dehydrogenase deficiency, could reduce the sensitivity of OTOFTs for beta thalassaemia to below $70 \%$. Our results highlight a potential hazard of the widespread application of OTOFTs and emphasize the fact that the public health impact of any single genetic adaptation to malaria cannot be considered in isolation.

\section{Authors' details \\ 'University of Oxford Zoology Department, Oxford, UK. ${ }^{2}$ Weatherall Institute of Molecular Medicine, Oxford, UK.}

Published: 22 September 2014

'University of Oxford Zoology Department, Oxford, UK

Full list of author information is available at the end of the article
doi:10.1186/1475-2875-13-S1-013

Cite this article as: Penman et al: Epistasis and the sensitivity of phenotypic screens for beta thalassaemia. Malaria Journal 2014 13(Suppl 1):013.
Submit your next manuscript to BioMed Central and take full advantage of:

- Convenient online submission

- Thorough peer review

- No space constraints or color figure charges

- Immediate publication on acceptance

- Inclusion in PubMed, CAS, Scopus and Google Scholar

- Research which is freely available for redistribution
() Biomed Central
C Biomed Central

(c) 2014 Penman et al; licensee BioMed Central Ltd. This is an Open Access article distributed under the terms of the Creative Commons Attribution License (http://creativecommons.org/licenses/by/4.0), which permits unrestricted use, distribution, and reproduction in any medium, provided the original work is properly cited. The Creative Commons Public Domain Dedication waiver (http:// creativecommons.org/publicdomain/zero/1.0/) applies to the data made available in this article, unless otherwise stated. 